
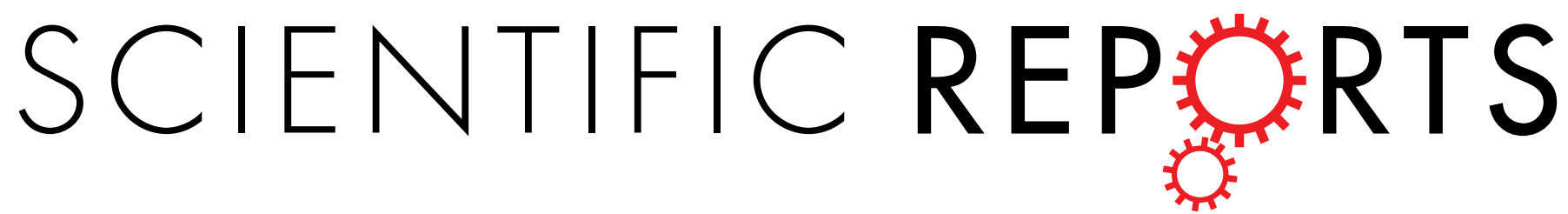

\title{
OPEN
}

Received: 18 March 2015

Accepted: 22 June 2015

Published: 17 July 2015

\section{Diversity and distribution of 165 rRNA and phenol monooxygenase genes in the rhizosphere and endophytic bacteria isolated from PAH-contaminated sites}

\author{
Anping Peng ${ }^{*}$, Juan Liu*, Wanting Ling, Zeyou Chen \& Yanzheng Gao
}

This is the first investigation of the diversity and distribution of $16 \mathrm{~S} \mathrm{rRNA}$ and phenol monooxygenase (PHE) genes in endophytic and rhizosphere bacteria of plants at sites contaminated with different levels of PAHs. Ten PAHs at concentrations from 34.22 to 55.29 and 45.79 to $97.81 \mathrm{mg} \cdot \mathrm{kg}^{-1}$ were measured in rhizosphere soils of Alopecurus aequalis Sobol and Oxalis corniculata L., respectively. The diversity of $16 \mathrm{~S}$ rRNA and PHE genes in rhizosphere soils or plants changed with varying PAH pollution levels, as shown based on PCR-DGGE data. Generally, higher Shannon-Weiner indexes were found in mild or moderate contaminated areas. A total of 82 different bacterial $16 \mathrm{~S}$ rRNA gene sequences belonging to five phyla; namely, Acfinobacteria, Proteobacteria, Chloroflexi, Cyanophyta, and Bacteroidetes, were obtained from rhizosphere soils. For the 57 identified PHE gene sequences, 18 were excised from rhizosphere bacteria and 39 from endophytic bacteria. The copy numbers of $16 \mathrm{~S}$ rRNA and PHE genes in rhizosphere and endophytic bacteria varied from $3.83 \times 10^{3}$ to $2.28 \times 10^{6}$ and $4.17 \times 10^{2}$ to $1.99 \times 10^{5}$, respectively. The copy numbers of PHE genes in rhizosphere bacteria were significantly higher than in endophytic bacteria. Results increase our understanding of the diversity of rhizosphere and endophytic bacteria from plants grown in PAHcontaminated sites.

Polycyclic aromatic hydrocarbons (PAHs) are a class of typical organic pollutants comprised of two or more benzene rings ${ }^{1}$. PAHs are of great concern due to their mutagenic and carcinogenic potential. Once released into the environment, PAHs are sorbed to the organic fraction of soils ${ }^{2}$. PAHs can enter the food chain through plant uptake of these hydrophobic contaminates from soil, which can damage human health and endanger the ecological environment. Utilizing PAH-degrading bacteria to remedy $\mathrm{PAH}$-contaminated soils and reduce plant PAH pollution risk has attracted much attention in recent years $^{3-5}$. Rhizospheric and endophytic bacteria have PAH biodegradation potential and are widely distributed in the organs and rhizosphere of plants growing in PAH-polluted sites ${ }^{6-9}$.

Endophytic bacteria reside within the interior tissues of plants without causing harm to either the host plant or the environment ${ }^{10}$. Several endophytic bacteria and functional genes play important roles in degrading PAH-pollutants ${ }^{8,11,12}$. Investigating the ecological structure and diversity of these endophytic bacteria and PAH-degrading genes in contaminated sites is particularly important for their application in biological remediation. Our previous study revealed that PAH pollution can significantly impact the

Institute of Organic Contaminant Control and Soil Remediation, College of Resource and Environmental Sciences, Nanjing Agricultural University, Nanjing 210095, P.R. China. *These authors contributed equality to this work. Correspondence and requests for materials should be addressed to Y.Z.G. (email: gaoyanzheng@njau.edu.cn or gaosoil@163.com) 


\begin{tabular}{|c|c|c|c|c|c|c|}
\hline \multirow[b]{2}{*}{ PAHs } & \multicolumn{3}{|c|}{$\begin{array}{c}\text { The rhizosphere soils of } A \text {. aequalis }\left(\mathrm{mg} \cdot \mathrm{kg}^{-1} \text { dry }\right. \\
\text { weight) }\end{array}$} & \multicolumn{3}{|c|}{$\begin{array}{c}\text { The rhizosphere soils of } O \text {. corniculata }\left(\mathrm{mg} \cdot \mathrm{kg}^{-1} \text { dry }\right. \\
\text { weight) }\end{array}$} \\
\hline & A & $\mathbf{Z}$ & $\mathbf{Q}$ & $\mathbf{A}$ & $\mathrm{Z}$ & $\mathbf{Q}$ \\
\hline NAP & $32.12 \pm 3.18 \mathrm{a}$ & $26.99 \pm 4.04 \mathrm{~b}$ & $21.77 \pm 5.43 c$ & $51.24 \pm 2.89 \mathrm{a}$ & $32.65 \pm 3.96 b$ & $29.68 \pm 2.37 c$ \\
\hline FLU & $1.89 \pm 0.04 \mathrm{a}$ & $0.99 \pm 0.02 b$ & $0.79 \pm 0.21 \mathrm{c}$ & $3.12 \pm 0.06 \mathrm{a}$ & $2.8 \pm 0.64 \mathrm{~b}$ & $2.15 \pm 0.32 \mathrm{c}$ \\
\hline ANY & $0.88 \pm 0.02 b$ & $0.80 \pm 0.47 \mathrm{~b}$ & $0.96 \pm 0.01 \mathrm{a}$ & $5.65 \pm 0.37 \mathrm{a}$ & $3.66 \pm 0.04 b$ & $3.05 \pm 0.23 \mathrm{~b}$ \\
\hline PHA & $10.34 \pm 1.89 \mathrm{a}$ & $7.34 \pm 0.59 b$ & $4.57 \pm 0.75 c$ & $12.68 \pm 1.71 \mathrm{a}$ & $9.96 \pm 1.66 \mathrm{~b}$ & $4.35 \pm 0.23 c$ \\
\hline FLA & $2.85 \pm 0.43 \mathrm{a}$ & $2.13 \pm 0.21 b$ & $1.35 \pm 0.04 c$ & $4.63 \pm 0.41 \mathrm{a}$ & $1.25 \pm 0.09 b$ & $0.79 \pm 0.02 c$ \\
\hline $\mathrm{CHR}$ & $4.17 \pm 0.60 \mathrm{a}$ & $3.67 \pm 0.26 b$ & $1.99 \pm 0.03 c$ & $10.39 \pm 0.65 a$ & $4.06 \pm 0.41 \mathrm{~b}$ & $1.31 \pm 0.01 \mathrm{c}$ \\
\hline PYR & $0.86 \pm 0.04 \mathrm{~b}$ & $0.94 \pm 0.01 \mathrm{a}$ & $0.92 \pm 0.02 \mathrm{ab}$ & $3.33 \pm 0.19 a$ & $1.89 \pm 0.02 b$ & $1.53 \pm 0.02 b$ \\
\hline $\mathrm{BaA}$ & $0.67 \pm 0.03 \mathrm{a}$ & $0.53 \pm 0.00 \mathrm{~b}$ & $0.51 \pm 0.00 \mathrm{~b}$ & $2.46 \pm 0.31 \mathrm{a}$ & $1.63 \pm 0.08 b$ & $1.62 \pm 0.07 b$ \\
\hline $\mathrm{BbF}$ & $0.77 \pm 0.00 \mathrm{a}$ & $0.8 \pm 0.05 a$ & $0.67 \pm 0.00 \mathrm{~b}$ & $3.74 \pm 0.04 \mathrm{a}$ & $1.99 \pm 0.05 b$ & $0.8 \pm 0.00 c$ \\
\hline BghiP & $0.74 \pm 0.13 \mathrm{a}$ & $0.68 \pm 0.11 b$ & $0.69 \pm 0.01 b$ & $0.57 \pm 0.02 \mathrm{a}$ & $0.67 \pm 0.00 \mathrm{a}$ & $0.51 \pm 0.04 \mathrm{a}$ \\
\hline ¿PAHs & $55.29 \pm 5.19 a$ & $44.87 \pm 6.34 b$ & $34.22 \pm 7.98 c$ & $97.81 \pm 10.10 \mathrm{a}$ & $60.56 \pm 9.28 b$ & $45.79 \pm 5.49 c$ \\
\hline
\end{tabular}

Table 1. Concentrations of PAHs in: rhizosphere soils $\left(\mathbf{m g} \cdot \mathrm{kg}^{-1}\right.$ dry weight). Note: different letters in the same row for the same plant indicate significant differences $(P<0.05)$.

distribution and community structure of endophytic bacteria in plants from PAH-contaminated sites ${ }^{13}$, but we did not explore PAH-degrading genes at such sites.

Rhizosphere bacteria are isolated from rhizosphere soil ${ }^{14}$, and can increase host plant tolerance to abiotic stress by improving their nutritional status ${ }^{15}$, inhibiting plant disease $e^{16}$, and degrading toxic xenobiotic substances ${ }^{6}$. Previous studies have shown that plant species ${ }^{17}$, metabolic types, and environmental conditions $^{18}$ can have specific effects on rhizosphere bacterial communities. The community structures of rhizosphere bacteria in heavy metal- or pesticide-contaminated environments have been investigated ${ }^{19-21}$. Pritchina et al. ${ }^{22}$ used a terminal restriction fragment length polymorphism (TRFLP) technique to investigate the rhizosphere bacterial communities of four types of plant grown in the presence of different PAH-contaminated soils; the results showed that the level of PAH pollution had a more significant influence on the rhizosphere bacterial community structure than did the type of host plant. Rhizosphere width (distance from root surface) also affected the bacterial species and quantities ${ }^{23}$. However, limited information is available on the relationship between rhizosphere bacteria and endophytic bacteria in PAH-polluted sites.

Microorganisms can adapt to organic pollution stress by regulating the expression of biodegradation-related genes ${ }^{24}$. Monooxygenase plays an important role in microbial biodegradation of PAHs ${ }^{25}$. The phenol monooxygenase (PHE) gene and several other aromatic oxygenase genes (e.g., toluene/naphthalene/chlorobenzene dioxygenase and ring hydroxylating monooxygenases) are typically used as indicator genes because of their substrate specificity, high conservation, and being the rate-limiting component in aromatic hydrocarbon biodegradation ${ }^{22,26-28}$. Therefore, investigations of $\mathrm{PAH}$-degrading genes as well as the diversity and distribution of rhizospheric and endophytic bacteria in PAH-contaminated sites is particularly important; this is also a prerequisite for use of PAH-degradable bacteria to eliminate soil PAH contamination and reduce plant PAH risk.

In this report, we selected two plants; namely, Alopecurus aequalis Sobol (A. aequalis) and Oxalis corniculata L. (O. corniculata), because they predominated at a PAH-contaminated site. Using a denaturing gradient gel electrophoresis (PCR-DGGE) method combined with fluorogenic quantitative PCR (FQ-PCR) technology, the diversity and distribution of $16 \mathrm{~S}$ rRNA and phenol monooxygenase genes of rhizospheric and endophytic bacteria in these two plants were studied for the first time. The results increase our understanding of bacterial ecological functions and contributions to the defense against $\mathrm{PAH}$ pollution stress and reduction of $\mathrm{PAH}$ pollution risk.

\section{Results}

In this study, $10 \mathrm{PAHs}$ designated by the US Environmental Protection Agency as priority pollutants were detected in rhizosphere soils (Table 1): naphthalene (NAP), acenaphthylene (ANY), fluorine (FLU), phenanthrene (PHA), fluoranthene (FLA), pyrene (PYR), benz[a] anthracene (BaA), chrysene (CHR), benzo[b]fluoranthene $(\mathrm{BbF})$, and benzo[ghi]perylene (BghiP). The PAH concentrations in rhizosphere soils of both plants decreased with increasing distance from the aromatics factory. Among them, NAP and PHA were the primary PAHs in the rhizosphere soils of both A. aequalis and O. corniculata, accounting for 76.51 to $76.97 \%$ and 65.35 to $86.87 \%$ of the total concentrations, respectively. Interestingly, regardless of the PAH pollution level, the rhizosphere soils of $O$. corniculata accumulated greater quantities of PAHs; the contents of PAHs were 1.34-, 1.35-, and 1.77-fold, respectively, higher than A. aequalis rhizosphere soil from the $\mathrm{Q}$ to $\mathrm{A}$ area. 


\begin{tabular}{|c|c|c|c|c|c|c|c|c|c|c|c|c|}
\hline \multirow[b]{3}{*}{ PAHs } & \multicolumn{6}{|c|}{ A. aequalis } & \multicolumn{6}{|c|}{ O. corniculata } \\
\hline & \multicolumn{3}{|c|}{ Root } & \multicolumn{3}{|c|}{ Shoot } & \multicolumn{3}{|c|}{ Root } & \multicolumn{3}{|c|}{ Shoot } \\
\hline & A & $\mathrm{z}$ & Q & A & $\mathrm{Z}$ & Q & A & $\mathrm{Z}$ & $\mathbf{Q}$ & $\mathbf{A}$ & $\mathrm{Z}$ & $\mathbf{Q}$ \\
\hline NAP & $15.76 \pm 1.00 \mathrm{a}$ & $12.65 \pm 1.26 \mathrm{~b}$ & $11.51 \pm 0.39 c$ & $2.50 \pm 0.10 \mathrm{a}$ & $1.41 \pm 0.20 \mathrm{~b}$ & $1.13 \pm 0.15 b$ & $28.90 \pm 2.21 \mathrm{a}$ & $15.68 \pm 1.51 b$ & $13.92 \pm 0.35 b$ & $3.16 \pm 0.30 \mathrm{a}$ & $1.42 \pm 0.98 \mathrm{~b}$ & $1.34 \pm 0.45 b$ \\
\hline FLU & $1.13 \pm 0.08 \mathrm{a}$ & $0.54 \pm 0.00 \mathrm{~b}$ & $0.25 \pm 0.11 \mathrm{c}$ & $0.51 \pm 0.01 \mathrm{a}$ & $0.42 \pm 0.05 b$ & $0.32 \pm 0.01 \mathrm{c}$ & $1.69 \pm 0.37 \mathrm{a}$ & $0.62 \pm 0.19 b$ & $0.47 \pm 0.20 \mathrm{c}$ & $0.57 \pm 0.01 \mathrm{a}$ & $0.21 \pm 0.06 \mathrm{~b}$ & $0.22 \pm 0.04 \mathrm{~b}$ \\
\hline ANY & $1.12 \pm 0.03 \mathrm{a}$ & $1.00 \pm 0.01 \mathrm{a}$ & $0.79 \pm 0.04 \mathrm{~b}$ & $0.65 \pm 0.07 \mathrm{a}$ & $0.69 \pm 0.12 \mathrm{a}$ & $0.4 \pm 0.04 \mathrm{~b}$ & $1.92 \pm 0.40 \mathrm{a}$ & $1.28 \pm 0.15 \mathrm{a}$ & $1.15 \pm 0.02 \mathrm{a}$ & $0.32 \pm 0.01 \mathrm{~b}$ & $0.34 \pm 0.07 \mathrm{~b}$ & $0.57 \pm 0.17 \mathrm{a}$ \\
\hline ANE & $0.83 \pm 0.08 \mathrm{a}$ & $0.65 \pm 0.03 \mathrm{~b}$ & $0.5 \pm 0.00 \mathrm{c}$ & $0.76 \pm 0.01 \mathrm{a}$ & $0.47 \pm 0.04 \mathrm{~b}$ & $0.38 \pm 0.05 c$ & $2.09 \pm 0.38 \mathrm{a}$ & $1.41 \pm 0.07 \mathrm{~b}$ & $1.21 \pm 0.43 b$ & $1.33 \pm 0.01 \mathrm{a}$ & $0.96 \pm 0.06 \mathrm{a}$ & $0.32 \pm 0.04 \mathrm{~b}$ \\
\hline PHA & $1.04 \pm 0.15 \mathrm{a}$ & $0.78 \pm 0.07 \mathrm{~b}$ & $0.49 \pm 0.02 \mathrm{c}$ & $0.35 \pm 0.03 a$ & $0.3 \pm 0.04 \mathrm{a}$ & $0.28 \pm 0.03 \mathrm{~b}$ & $1.88 \pm 0.13 \mathrm{a}$ & $0.87 \pm 0.05 c$ & $1.17 \pm 0.38 \mathrm{~b}$ & $0.32 \pm 0.02 \mathrm{a}$ & $0.27 \pm 0.07 \mathrm{~b}$ & $0.37 \pm 0.02 \mathrm{a}$ \\
\hline FLA & $0.73 \pm 0.04 \mathrm{a}$ & $0.67 \pm 0.05 a$ & $0.52 \pm 0.01 \mathrm{a}$ & $0.29 \pm 0.03 \mathrm{a}$ & $0.28 \pm 0.02 \mathrm{a}$ & $0.26 \pm 0.02 \mathrm{a}$ & $1.61 \pm 0.40 \mathrm{a}$ & $0.96 \pm 0.15 b$ & $0.93 \pm 0.02 b$ & $0.46 \pm 0.02 \mathrm{a}$ & $0.4 \pm 0.01 \mathrm{a}$ & $0.29 \pm 0.00 \mathrm{~b}$ \\
\hline CHR & $0.82 \pm 0.02 \mathrm{a}$ & $0.7 \pm 0.04 \mathrm{a}$ & $0.53 \pm 0.04 \mathrm{~b}$ & $0.45 \pm 0.02 \mathrm{a}$ & $0.4 \pm 0.06 \mathrm{a}$ & $0.39 \pm 0.04 \mathrm{a}$ & $2.31 \pm 0.08 \mathrm{a}$ & $1.08 \pm 0.10 \mathrm{~b}$ & $1.41 \pm 0.30 \mathrm{~b}$ & $0.59 \pm 0.02 \mathrm{a}$ & $0.35 \pm 0.07 \mathrm{~b}$ & $0.37 \pm 0.01 b$ \\
\hline PYR & $0.36 \pm 0.02 \mathrm{a}$ & $0.38 \pm 0.03 \mathrm{a}$ & $0.32 \pm 0.00 \mathrm{a}$ & $0.17 \pm 0.01 \mathrm{a}$ & $0.15 \pm 0.02 \mathrm{a}$ & $0.12 \pm 0.01 \mathrm{a}$ & $0.69 \pm 0.01 \mathrm{a}$ & $0.65 \pm 0.26 \mathrm{a}$ & $0.49 \pm 0.09 \mathrm{~b}$ & $0.29 \pm 0.03 a$ & $0.18 \pm 0.04 \mathrm{~b}$ & $0.16 \pm 0.00 \mathrm{~b}$ \\
\hline $\mathrm{BaA}$ & $0.58 \pm 0.03 \mathrm{a}$ & $0.53 \pm 0.02 \mathrm{a}$ & $0.48 \pm 0.04 \mathrm{~b}$ & $0.29 \pm 0.02 \mathrm{a}$ & $0.23 \pm 0.01 \mathrm{a}$ & $0.21 \pm 0.01 \mathrm{a}$ & $1.51 \pm 0.34 \mathrm{a}$ & $1.09 \pm 0.05 \mathrm{a}$ & $0.83 \pm 0.03 \mathrm{a}$ & $0.37 \pm 0.03 a$ & $0.28 \pm 0.03 \mathrm{~b}$ & $0.24 \pm 0.00 \mathrm{~b}$ \\
\hline $\begin{array}{l}\sum \mathrm{PA} \\
\mathrm{Hs}\end{array}$ & $22.37 \pm 1.41 \mathrm{a}$ & $17.9 \pm 0.95 b$ & $15.39 \pm 1.21 \mathrm{~b}$ & $5.97 \pm 0.09 a$ & $4.34 \pm 0.55 b$ & $3.49 \pm 0.38 \mathrm{c}$ & $52.69 \pm 2.54 \mathrm{a}$ & $29.7 \pm 1.98 \mathrm{~b}$ & $27.62 \pm 1.04 \mathrm{~b}$ & $9.77 \pm 0.05 \mathrm{a}$ & $6.15 \pm 1.03 \mathrm{~b}$ & $5.63 \pm 0.79 c$ \\
\hline
\end{tabular}

Table 2. Concentrations of PAHs in: plants $\left(\mathbf{m g} \cdot \mathbf{k g}^{-1}\right.$ dry weight). Note: different letters in the same row for the same plant root or shoot indicate significant differences $(P<0.05)$.

Excluding BbF and BghiP, the remaining nine PAHs found in rhizosphere soils were also detected in the roots and shoots of both plants (Table 2). As the concentration of PAHs increased in rhizosphere soil (from Q to A), the accumulation of PAHs in plants also increased, the overwhelming majority of which accumulated in roots (Supplementary Figure S1). Similar to rhizosphere soils, the PAH-accumulating ability of $O$. corniculata was greater than that of $A$. aequalis; 1.66 to 2.36 - and 1.42 to 1.64 -fold higher in roots and shoots at the various sampling sites. Among detectable PAHs, the concentrations of NAP and PHA in both plants were higher, e.g., the total concentrations of NAP plus PHA accounted for 75.03 to $77.97 \%$ and 39.40 to $47.74 \%$ of the total PAH concentrations in roots and shoots of A. aequalis, respectively.

Detection of $16 \mathrm{~S}$ rRNA genes of rhizosphere bacteria using PCR-DGGE. PCR-DGGE profiles of $16 \mathrm{~S}$ rRNA genes in rhizosphere bacteria are shown in Fig. 1. The presence of $\geq 30$ detectable bands in each sample suggested that a significant number of species of rhizosphere bacteria were present in PAH-contaminated rhizosphere soils. Bands 1 and 2 were detected in all samples, indicating that the rhizosphere bacteria represented by these two bands predominated in rhizosphere soils of both plants. However, the species, distribution, and diversity of bacteria in rhizosphere soils differed according to the rhizosphere soil and PAH pollution level. For example, Band 3 was dominant in rhizosphere soils of $A$. aequalis at low and moderate $\mathrm{PAH}$-contaminated sites ( $\mathrm{Q}$ and $\mathrm{Z})$, but not at high $\mathrm{PAH}$-contaminated sites (A). Band 4 only presented in rhizosphere soils of $O$. corniculata at site Q. Overall, compared to sites $\mathrm{A}$ and $\mathrm{Z}$ (corresponding to higher levels of PAH contamination), the rhizosphere soil samples collected from a lightly contaminated area ( $Q$ site) had a greater number of bands, which indicated that the increasing PAH contamination level decreases the number of rhizosphere bacterial species. This is supported by the more prominent dominant bands at areas with moderate or high level PAH pollution ( $\mathrm{Z}$ and $\mathrm{A}$ sites).

The preponderance of dominant bands in the DGGE gel were sequenced, and 82 different bacterial sequences were obtained after removing the $16 \mathrm{~S}$ rRNA and $18 \mathrm{~S}$ rRNA genes of mitochondria and chloroplasts, among which 37 were isolated from $A$. aequalis rhizosphere soils and 45 from $O$. corniculata rhizosphere soils. Phylogenetic analysis showed that the total bacterial sequences were classified into five phyla (Acfinobacteria, Proteobacteria, Chloroflexi, Cyanophyta, and Bacteroidetes) and eight classes (Actinobacteria, $\alpha$-proteobacteria, $\gamma$-proteobacteria, Anaerolineae, Cyanophyceae, Flavobacteria, Sphingobacteria, and Bacteroidetes) (Fig. 2). The majority of isolates from the rhizosphere soils of the two plant species belonged to Actinobacteria (48.6\% of the sequences isolated from A. aequalis and $53.3 \%$ of those isolated from O. corniculata), followed by Proteobacteria $(21.6 \%$ and $33.3 \%$ for the two rhizosphere soils).

Detection of the phenol monooxygenase gene in rhizospheric and endophytic bacteria using PCR-DGGE. The phenol monooxygenase (PHE) gene was detected in rhizosphere and endophytic bacteria at the various PAH-polluted sites (Fig. 3). Using the DGGE fingerprint atlas, we can see that all detected samples contained dominant bands. After excising these bands from the gel, purification, cloning, sequencing, and using the NCBI database and nucleotide BLAST (http://blast.ncbi.nlm.nih. gov/Blast.cgi), we showed that these bands represented the phenol monooxygenase gene. The data in Fig. 3 suggest that plant type, plant tissue, and PAH-pollution levels significantly impact the distribution of PHE genes in both rhizosphere and endophytic bacteria; this is similar to the 16S rRNA gene in 


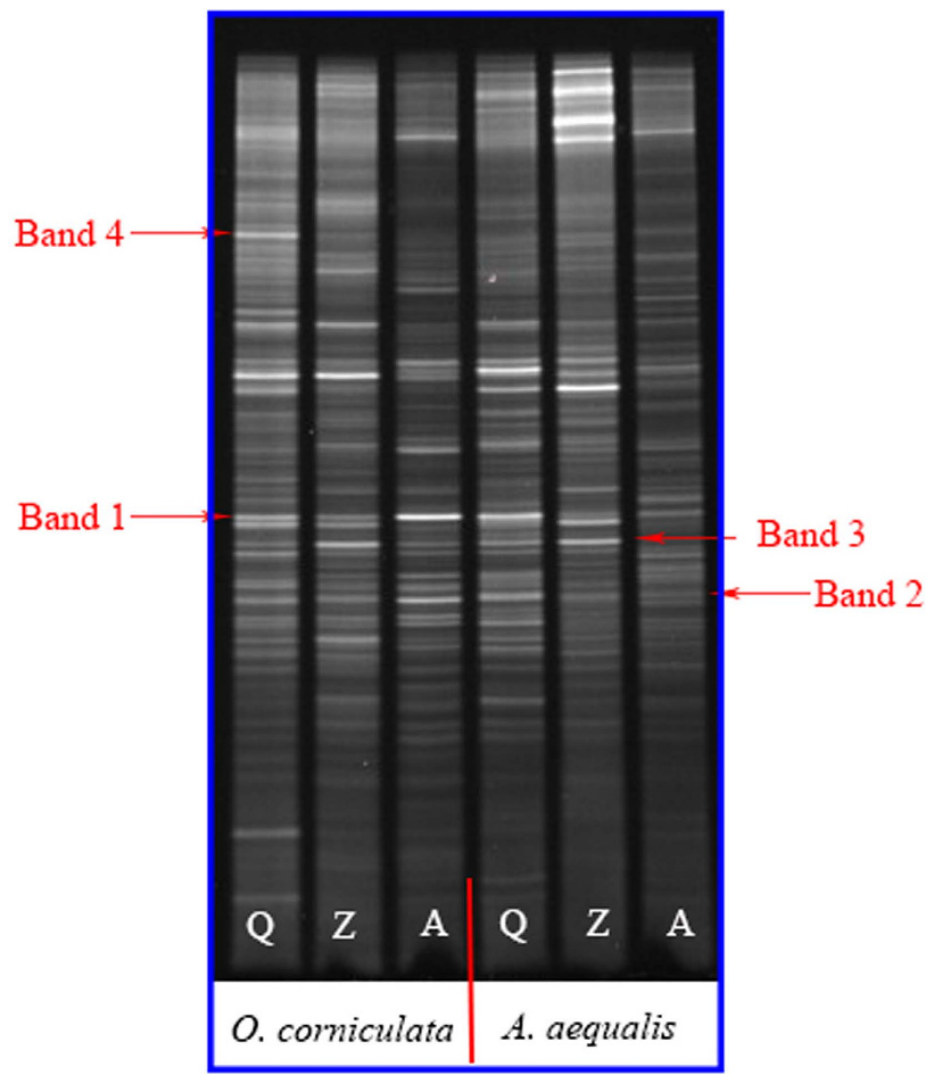

Figure 1. DGGE gel of the $16 \mathrm{~S}$ rRNA gene of rhizosphere bacteria.

rhizosphere bacteria. For example, band 5 was present only in rhizosphere bacteria of $O$. corniculata at site A, and band 6 was observed only in endophytic bacteria in the shoot of A. aequalis. In total, 57 bands were sequenced and analyzed, among which 18 were excised from rhizosphere bacteria (A. aequalis - 6; O. corniculata - 12), and 39 from endophytic bacteria (A. aequalis - 21; O. corniculata - 18) (Fig. 4). These 57 sequenced bands closely matched phenol monooxygenase gene sequences in the GenBank database with high sequence identities (86 to 95\%). The bands detected were derived from Pseudomonas sp., Variovorax sp., Alcaligenes sp., and uncultured bacteria.

To explore the diversity of 16SrRNA and PHE genes in rhizosphere and endophytic bacteria, Shannon-Weiner and Simpson indexes were calculated (Table 3). The Shannon-Weiner indexes of 16S rRNA and PHE genes in rhizosphere bacteria were similar among the various pollution levels, with values ranging from 3.25 to 3.45 and 3.06 to 3.39 , respectively. However, greater variation in the diversity of endophytic bacteria according to pollution level was detected; i.e., the Shannon-Weiner index of $16 \mathrm{~S}$ rRNA and PHE genes in endophytic bacteria ranged from 2.55 to 3.40 and 1.34 to 2.42 , respectively. Compared with A. aequalis, the diversity of endophytic bacteria in O. corniculata was higher at almost all sampling positions (0.87 to 1.12-fold higher), but the diversity of PHE genes was lower (0.80 to 0.94 -fold higher). A lower Shannon-Weiner index but a higher Simpson index for endophytic than rhizosphere bacteria at the same pollution level in most situations could be due to the presence of considerably greater numbers of rhizosphere bacteria under certain circumstances ${ }^{29}$. Furthermore, the high concentrations of PAHs in rhizosphere soils may contribute to this difference.

The $16 \mathrm{~S}$ rRNA gene copies in rhizospheric and endophytic bacteria. In recent years, use of FQ-PCR to analyze the formation and quantitative distribution of bacteria and genes has attracted extensive attention ${ }^{30,31}$. The 16S rRNA and PHE gene copy numbers in rhizosphere and endophytic bacteria determined using FQ-PCR are shown in Fig. 5 and Table 4. There was a marked difference between the $16 \mathrm{~S}$ rRNA and PHE gene copy numbers in rhizosphere and endophytic bacteria. For rhizosphere bacteria, the 16S rRNA gene copy numbers were considerably higher than the PHE gene copy numbers in both plants (16.31 to 142.34 -fold higher depending on the pollution levels). In addition, the copy numbers of both genes decreased with increasing PAH pollution. For example, at position A, the $16 \mathrm{~S}$ rRNA gene copy numbers in A. aequalis and O. corniculata were $5.69 \times 10^{5}$ and $2.26 \times 10^{7}$, respectively. At position $\mathrm{C}$, the $16 \mathrm{~S}$ rRNA gene copy numbers increased to $4.84 \times 10^{6}$ and $1.04 \times 10^{8}$, respectively, for the two plants. Comparing the two types of plants, the $16 \mathrm{~S}$ rRNA gene copy numbers in rhizosphere bacteria of 


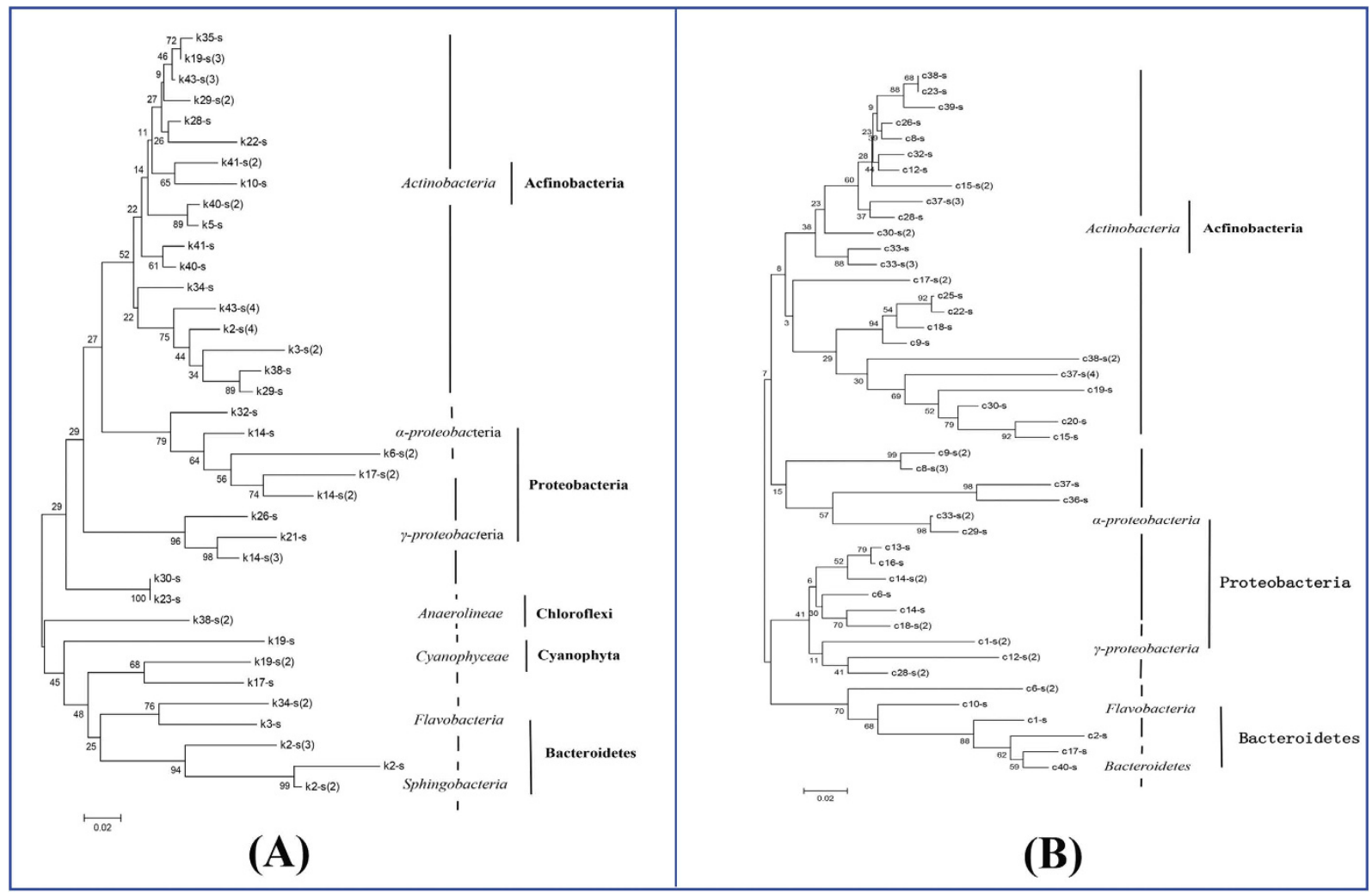

Figure 2. Phylogenetic trees based on 16S rRNA gene analysis of rhizosphere bacterial community of (A) A. aequalis and (B) O. corniculata.

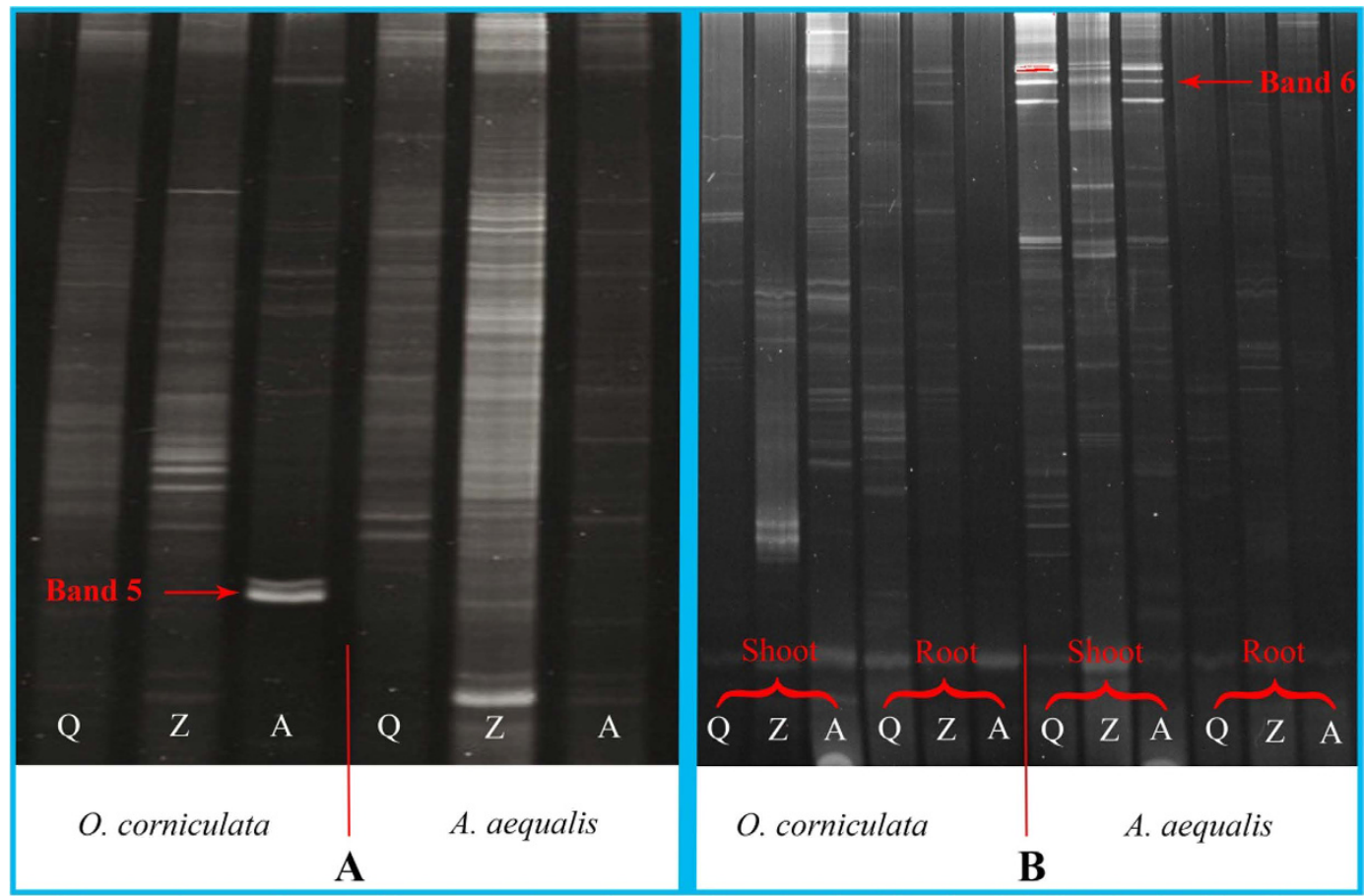

Figure 3. A DGGE gel of the PHE gene from (A) rhizosphere bacteria and (B) endophytic bacteria. 


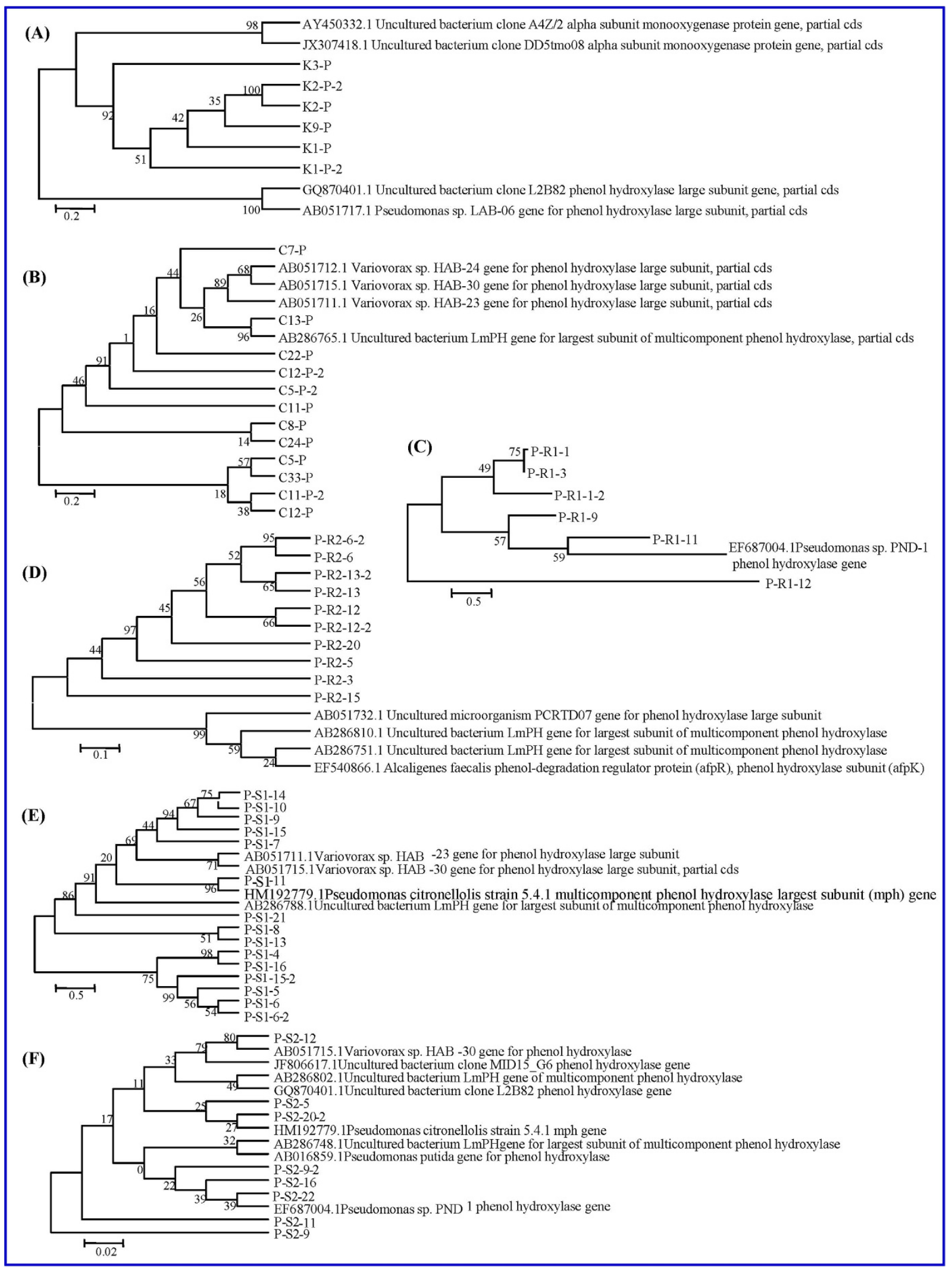

Figure 4. Phylogenetic trees constructed by PHE gene sequence analysis of the rhizosphere bacterial community of (A) A. aequalis and (B) O. corniculata and endophytic bacterial community: (C) Root of $A$. aequalis; (D) Shoot of A. aequalis; (E) Root of O. corniculata; (F) Shoot of O. corniculata. 


\begin{tabular}{|c|c|c|c|c|c|c|c|c|c|c|c|}
\hline \multirow[b]{2}{*}{ Gene } & \multirow[b]{2}{*}{ Diversity index } & \multirow[b]{2}{*}{ Plant } & \multicolumn{3}{|c|}{ Rhizosphere bacteria } & \multicolumn{3}{|c|}{$\begin{array}{l}\text { Endophytic bacteria } \\
\text { in root }\end{array}$} & \multicolumn{3}{|c|}{$\begin{array}{l}\text { Endophytic bacteria } \\
\text { in shoot }\end{array}$} \\
\hline & & & A & $\mathrm{z}$ & $\mathbf{Q}$ & $\mathbf{A}$ & $\mathrm{Z}$ & $\mathbf{Q}$ & $\mathbf{A}$ & $\mathrm{Z}$ & $\mathbf{Q}$ \\
\hline \multirow{4}{*}{$16 \mathrm{~S}$ rRNA } & Shannon-Weiner index & A. aequalis & 3.25 & 3.31 & 3.33 & 2.93 & 3.2 & 3.38 & 2.74 & 3.03 & 2.55 \\
\hline & & O. corniculata & 3.35 & 3.28 & 3.45 & 3.29 & 3.27 & 3.34 & 2.73 & 2.66 & 2.78 \\
\hline & Simpson index & A. aequalis & 0.042 & 0.04 & 0.04 & 0.057 & 0.043 & 0.037 & 0.071 & 0.055 & 0.095 \\
\hline & & O. corniculata & 0.037 & 0.039 & 0.034 & 0.039 & 0.042 & 0.037 & 0.082 & 0.078 & 0.071 \\
\hline \multirow{4}{*}{ PHE } & Shannon-Weiner index & A. aequalis & 3.13 & 3.28 & 3.23 & 2.01 & 2.13 & 1.23 & 1.68 & 2.42 & 2.21 \\
\hline & & O. corniculata & 3.06 & 3.21 & 3.39 & 1.62 & 1.88 & 2.05 & 1.34 & 2.28 & 1.96 \\
\hline & Simpson index & A. aequalis & 0.047 & 0.042 & 0.036 & 0.137 & 0.054 & 0.109 & 0.227 & 0.102 & 0.143 \\
\hline & & O. corniculata & 0.054 & 0.043 & 0.038 & 0.08 & 0.196 & 0.052 & 0.08 & 0.121 & 0.157 \\
\hline
\end{tabular}

Table 3. Diversity analysis of $16 \mathrm{~S}$ rRNA and PHE genes in rhizosphere and endophytic bacteria.

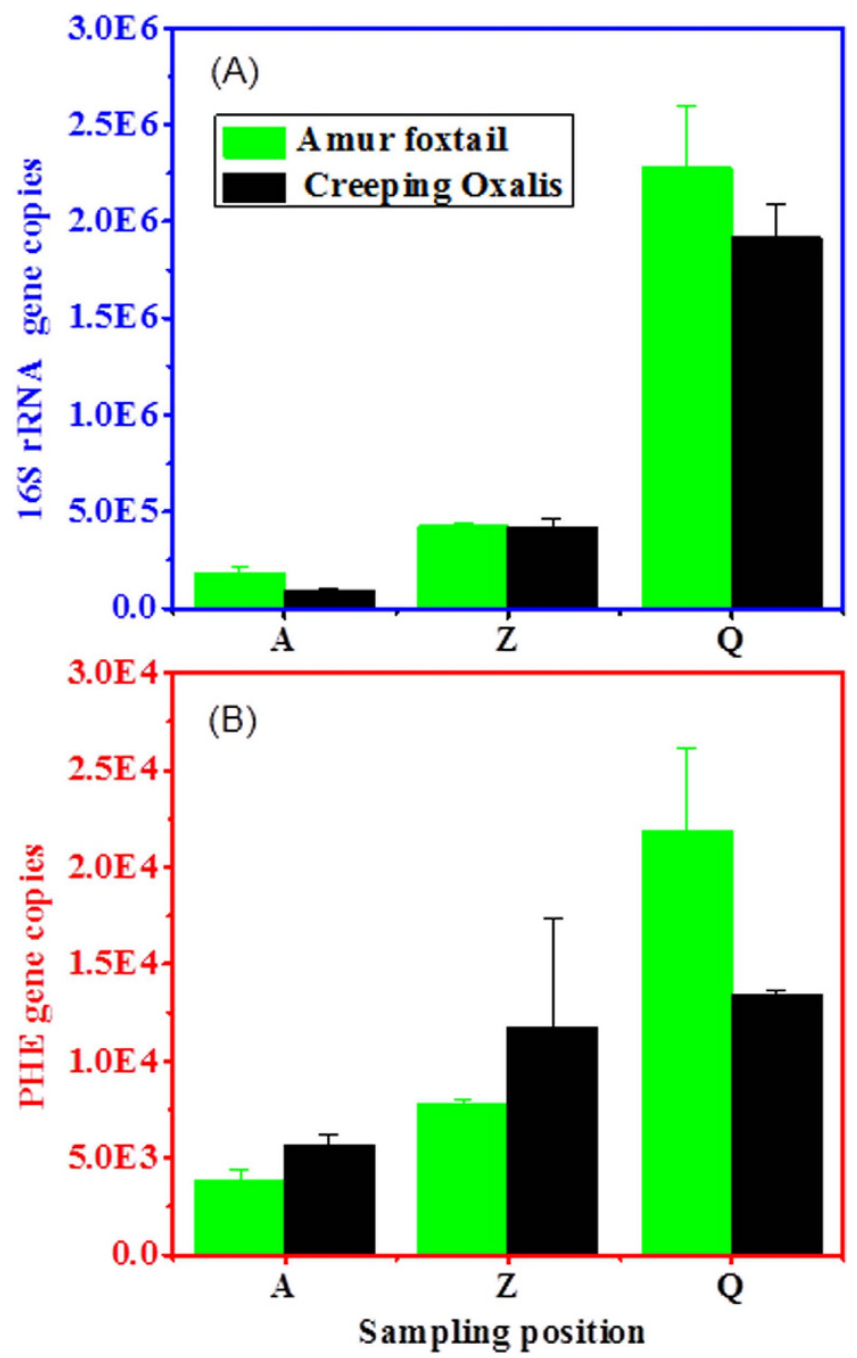

Figure 5. (A) $16 \mathrm{~S}$ rRNA and (B) PHE gene copy numbers in rhizosphere bacteria of two plant species as determined by FQ-PCR.

A. aequalis were higher than those in O. corniculata at all sampling positions, while for PHE genes at the $\mathrm{Q}$ and $\mathrm{Z}$ sites, the rhizosphere bacteria of $\mathrm{O}$. corniculata carried more PHE genes than $A$. aequalis, but at the A site, the number of PHE gene copies was up to 2.31-fold higher for A. aequalis than O. corniculata.

Similar to rhizosphere bacteria, the copy numbers of the two genes in endophytic bacteria differed significantly according to plant tissue and PAH concentration (Table 4). The copy numbers of 16S rRNA gene in shoot tissues were less than that in root tissues, regardless of the PAH pollution level; however, 


\begin{tabular}{|l|c|c|c|c|c|}
\hline \multirow{2}{*}{ Gene } & \multirow{2}{*}{ A. aequalis } & \multicolumn{2}{c|}{ O. corniculata } \\
\cline { 3 - 6 } & & Root & Shoot & Root & Shoot \\
\hline \multirow{3}{*}{16 S rRNA } & $\mathrm{A}$ & $5.23 \times 10^{5} \pm 1.22 \times 10^{3}$ & $4.61 \times 10^{4} \pm 5.11 \times 10^{3}$ & $2.21 \times 10^{7} \pm 8.93 \times 10^{5}$ & $5.54 \times 10^{5} \pm 2.93 \times 10^{4}$ \\
\cline { 2 - 6 } & $\mathrm{Z}$ & $1.36 \times 10^{7} \pm 5.52 \times 10^{4}$ & $3.76 \times 10^{6} \pm 5.04 \times 10^{5}$ & $2.49 \times 10^{7} \pm 5.43 \times 10^{4}$ & $1.21 \times 10^{6} \pm 1.91 \times 10^{4}$ \\
\cline { 2 - 6 } & $\mathrm{Q}$ & $4.64 \times 10^{6} \pm 4.50 \times 10^{4}$ & $1.95 \times 10^{5} \pm 2.72 \times 10^{3}$ & $1.02 \times 10^{8} \pm 4.61 \times 10^{6}$ & $1.78 \times 10^{6} \pm 2.42 \times 10^{4}$ \\
\hline \multirow{3}{*}{ PHE } & $\mathrm{A}$ & $3.56 \times 10^{3} \pm 3.22 \times 10^{2}$ & $\mathrm{~N} / \mathrm{A}$ & $\mathrm{N} / \mathrm{A}$ & $8.22 \times 10^{3} \pm 2.97 \times 10^{2}$ \\
\cline { 2 - 6 } & $\mathrm{Z}$ & $1.47 \times 10^{2} \pm 9.29$ & $1.96 \times 10^{3} \pm 7.78$ & $4.84 \times 10^{3} \pm 1.10 \times 10^{2}$ & $1.07 \times 10^{5} \pm 7.39 \times 10^{2}$ \\
\cline { 2 - 6 } & $\mathrm{Q}$ & $5.64 \times 10^{3} \pm 6.95$ & $5.73 \times 10^{3} \pm 1.39 \times 10^{2}$ & $1.23 \times 10^{4} \pm 8.91$ & $1.99 \times 10^{5} \pm 5.07 \times 10^{3}$ \\
\hline
\end{tabular}

Table 4. 16S rRNA and PHE gene copy numbers in endophytic bacteria of two plant species.

the opposite trend was observed for the PHE gene. For the same plant tissues, the 16S rRNA gene copy numbers in A. aequalis grown at medium-pollution sites were highest (2.93 to 26.00- and 19.28 to 81.56 -fold higher than at the other two sites in roots and shoots, respectively). However, the highest endophytic bacteria $16 \mathrm{~S}$ rRNA gene copy numbers in O. corniculata were observed at light pollution areas ( $\mathrm{Q}$ site), which were 4.10 to 4.62 - and 1.47 to 3.21 -fold higher than plants at $\mathrm{A}$ and $\mathrm{Z}$ sites in roots and shoots, respectively. For both plants, the PAH-degrading gene (PHE gene) copy numbers in endophytic bacteria increased with decreasing PAH content, and at the same sampling site the shoots commonly carried a greater number of PHE gene copies than roots.

\section{Discussion}

In this study, both A. aequalis and O. corniculata showed PAH uptake and accumulation ability, similar to previous reports ${ }^{13}$. At different PAH pollution levels, the RCF (defined as the ratio of the PAH concentration in roots to that in soils on a dry weight basis ${ }^{32}$ ) and SCF (defined as the ratio of the PAH concentration in shoots to that in soil on a dry weight basis) of total PAHs for A. aequalis were 0.399 to 0.450 and 0.097 to 0.108 , respectively, while the RCF and SCF of total PAHs for O. corniculata were 0.490 to 0.603 and 0.100 to 0.123 , respectively. The root tissues accumulated more PAHs from soils than shoot tissues at all sampling positions (Table 3), indicating that the PAHs in plant tissues are derived predominantly from root uptake from PAH-contaminated soils. This result is consistent with those reported by Gao and $\mathrm{Zhu}^{33}$, who investigated the capacity of 12 plant species to absorb and accumulate two PAHs (PHE and PYR). They found that SCFs of all plants accounted for $12.0 \%$ to $17.9 \%$ and $1.74 \%$ to $2.70 \%$ of RCFs for PHE and PYR, respectively. Compared with A. aequalis, O. corniculata has greater PAH accumulation ability, which was consistent with previous reports ${ }^{13}$. The RCFs and SCFs of O. corniculata at different positions were $122.93 \%$ to $134.12 \%$ and $92.51 \%$ to $120.56 \%$ higher than those in A. aequalis, respectively.

Previous studies have shown that endophytic bacteria are mainly derived from soil bacteria because the latter can pass into the plants through root fractures ${ }^{34}$, natural openings or wounds ${ }^{35}$, and seeds ${ }^{36}$, and then spread to the stems, leaves, and other organizations on the ground ${ }^{37}$. In this study, the majority of detected rhizosphere bacteria belonged to Actinobacteria and Proteobacteria, which is similar to the results of our study on the community structure of endophytic bacteria in the same two plant species ${ }^{19}$. To some extent, this result supported the concept that rhizosphere bacteria are the prime source of endophytic bacteria. Seghers et al. ${ }^{38}$ found that the community structure of endophytic bacteria in Zea mays L. was identical to that of the rhizosphere bacteria, and the number of bacteria in root was considerably greater than that in shoot. In our report, the 16S rRNA gene copy numbers in endophytic bacteria in plant roots were considerably higher than that in plant shoots (3.62 to 23.8- and 20.6 to 57.3-fold higher in A. aequalis and O. corniculata, respectively).

Using the DGGE method, the distribution and diversity of bacteria were measured using the Shannon-Weiner and Simpson indices. Tang et al. ${ }^{39}$ investigated the influence of heavy metals and PCBs on the microbial community of paddy soils and showed that the level of heavy metal and PCB pollution had a minor influence on bacterial community structure in paddy soils. Hassanshahian ${ }^{40}$ also found that bacteria isolated from uncontaminated sites have higher diversity compared to those from contaminated sites. In the present work, the diversities of rhizosphere bacteria were not significantly affected by PAH pollution levels. This finding is similar to the results of Altimira et al. ${ }^{41}$, who found that although the DGGE profiles of the bacteria changed under long-term Cu-pollution conditions, the Shannon-Weiner index was not affected. However, the diversities of endophytic bacteria and the PHE gene in rhizospheric and endophytic bacteria were affected by PAH pollution levels, which was consistent with previous reports ${ }^{19,42}$. Hendrickx ${ }^{42}$ et al. suggested that diversity of the BETX-degrading gene was determined by environmental conditions, including the contamination level.

Monooxygenases are a class of enzymes that play an important role in catalytic hydroxylation of aromatic compounds ${ }^{43}$, and the consequence of this biodegradation process is the production of phenolic intermediate products. In this study, the distributions and diversity of the phenol monooxygenase (PHE) gene in rhizosphere and endophytic bacteria of $A$. aequalis and $O$. corniculata grown in $\mathrm{PAH}$-contaminated sites were investigated. A certain level of environmental contaminants can promote the expression of 
catabolism-related genes responsible for the biodegradation of these pollutants. Altimira et al. ${ }^{41}$ showed that copper-resistance genes were present in the three $\mathrm{Cu}$-polluted soils, but not in the non-polluted soil. Siciliano et al. ${ }^{24}$ showed that alkB, $n d o B, n t d A a$, and $n t n M$ genes in plants are abundantly expressed, resulting in production of enzymes related to pollutant degradation, which in turn accelerates the metabolism of organic pollutants in plants. In this study, all plant samples accumulated a certain concentration of PAHs, and the PHE genes were detected in most plant tissues, excluding the shoot of A. aequalis and the root of $O$. corniculata in the area of high PAH concentration (A position). With an increase in PAH pollution level, the PHE gene diversity and copy number decreased in most situations; this is inconsistent with the study of Langworthy ${ }^{4}$, who found that the frequencies of PAH-degrading genes (nahA and $a l k B$ ) in the presence of moderate to high PAH concentrations increased. This discrepancy may due to the different living environments and the various bacterial species that carried the degrading genes.

One notes that the negative control sites (i.e. sites without PAHs but the plants) will be conducive to better clarify the influence of PAH contamination on the community structure and diversity of endophytic and rhizosphere bacteria in contaminated sites, but these negative control sites were not involved in this report. The main reason is due to the difficulties to find the proper PAH-free control sites not only with the same soil physical and chemical properties but also with the same dominant plants (A. aequalis and $O$. corniculata). Unfortunately, these control sites were not found in the sampling field. Despite the lack of negative controls, the changes of the diversity and distribution of 16S rRNA and phenol PHE genes in endophytic and rhizosphere bacteria of test plants contaminated with PAHs indicated that PAH contamination level plays a decisive role in bacterial community structure in PAH-contaminated sites.

The ecological structure and diversity of bacterial communities in anthropogenically polluted environments are good indicators ${ }^{39}$ and important prerequisites for bioremediation of organic contaminants. Screening and isolation of target bacteria and genes from rhizosphere soil or plant tissues, and then using them to remove PAHs from soils ${ }^{45}$, can effectively reduce the risk of plant organic contamination ${ }^{8,46}$ and protect food security, as well as human health. In this study, a number of rhizosphere bacteria, endophytic bacteria, and PAH-degrading genes were found in soil and plant samples suffering from long-term $\mathrm{PAH}$ pollution, indicating that these microorganisms can tolerate $\mathrm{PAH}$ pollution and have considerable potential to degrade PAHs. Further tests are required to explore the application of these isolates in organic pollution remediation technology. The mechanisms involved in gene regulation during the biodegradation of organic pollutants in two types of bacteria require further study. In addition, further studies are required on the interactions between these bacteria and plants. Overall, the insertion of genes associated with degradation of organic pollutants into common bacteria to construct engineered endophytic bacteria, and their induced colonization of host plants might accelerate the metabolism of organic pollutants.

\section{Conclusions}

This is the first investigation into the distribution and diversity of the 16S rRNA gene and PAH metabolism-related genes (phenol monooxygenase) in rhizosphere and endophytic bacteria in two common plants (A. aequalis and $O$. corniculata) grown in PAH-polluted sites. The results revealed large numbers of rhizosphere bacteria, endophytic bacteria, and phenol monooxygenase (PHE) genes in rhizosphere soils and host plants. PAH pollution levels can affect the distribution, diversity, and levels of rhizosphere bacteria, endophytic bacteria, and PHE genes in endophytic bacteria. Actinobacteria and Proteobacteria were the two major bacterial types detected, regardless of PAH pollution level. As pollution levels increased, the copy numbers of PHE genes in rhizosphere bacteria decreased significantly, but the diversity was unaffected. These results increase our understanding, and provide an important theoretical basis for application, of plant-related bacteria or PAH-degrading genes to eliminate $\mathrm{PAH}$ contamination and reduce the risks associated with plant $\mathrm{PAH}$ contamination.

\section{Methods}

Chemical reagents. A total of $16 \mathrm{PAH}$ standards dissolved in acetonitrile were purchased from Shanghai Anpel Scientific Instruments (Shanghai, China): naphthalene (NAP), acenaphthylene (ANY), acenaphthene (ANE), fluorine (FLU), phenanthrene (PHA), anthracene (ANT), fluoranthene (FLA), pyrene (PYR), benz[a]anthracene (BaA), chrysene (CHR), benzo[b]fluoranthene (BbF), benzo[k]fluoranthene $(\mathrm{BkF})$, benzo[a]pyrene $(\mathrm{BaP})$, indeno[1,2,3-cd] pyrene (InPy), dibenz[a,h]anthracene (DiahA), and benzo[ghi]perylene (BghiP). The concentration of each compound in the acetonitrile mixture was $200 \mathrm{mg} \cdot \mathrm{L}^{-1}$. $40 \%$ acrylamide / bis-acrylamide solution, $50 \times$ TAE buffer, and ammonium persulfate (APS) were obtained from Nanjing Chemical Reagent Co. Ltd. (Nanjing, China).

Sample collection. A. aequalis, O. corniculata, and rhizosphere soils of the two plants were obtained near an aromatics factory in Nanjing. Depending on the distance from the aromatics factory (from far to near), the sampling positions were named Q, $20-25 \mathrm{~m} ; \mathrm{Z}, 5-10 \mathrm{~m}$; and A, $0.3-0.5 \mathrm{~m}$, respectively. The physicochemical characteristics of the rhizosphere soils were as follows: $\mathrm{pH}, 5.87 ; 13.0 \%$ sand, $60.7 \%$ silt, $26.3 \%$ clay, and $1.36 \%$ organic matter. Plant samples were removed from the soil, carefully placed into a plastic bag, and immediately transported to the laboratory. Rhizosphere soil collection was performed as described by Barillot et al. ${ }^{47}$, with minor modifications. Briefly, after shaking the plants by hand 5 min to 
remove bulk soil, rhizosphere soil was collected by shaking the roots for $10 \mathrm{~min}$. Next, plants were gently rinsed with fresh water to remove adherent soil.

PAH analysis. Some of the rhizosphere soils and plant samples were freeze-dried immediately to determine the PAHs contents. PAHs were exacted from soil and plant samples, as described previously by Ling and $\mathrm{Gao}^{26}$. The concentrations of PAHs were analyzed using high-performance liquid chromatography (HPLC) with a reverse-phase C18 column (Inertsil ODS-SP, $5 \mu \mathrm{m}, 4.6 \times 150 \mathrm{~mm}$, GL Sciences Inc., Japan) using gradient elution.

Surface sterilization. The plant samples were surface sterilized as described previously by Sobral ${ }^{48}$ with minor modifications. Roots and shoots tissues were rinsed five times with deionized water, immersed in $75 \%(\mathrm{v} / \mathrm{v})$ ethanol for 3-5 min, washed with sterile water three times, immersed in $2 \%(\mathrm{v} / \mathrm{v})$ sodium hypochlorite for $3 \mathrm{~min}$, and rinsed with $75 \%$ ethanol for $30 \mathrm{~s}$. Finally, the samples were washed three times with sterilized distilled water to remove surface sterilization agents. To determine whether the sterilization process was successful, the sterile distilled water used in the final rinse was plated onto fresh beef extract peptone agar plates and incubated at $28^{\circ} \mathrm{C}$ for 7 days to detect any remaining epiphytic bacteria.

PCR-DGGE analysis. Total DNA extraction of rhizosphere bacterial community was performed using the Fast DNA Spin Kit for Soil (MP Biomedicals, USA) and total DNA extraction of endophytic was performed according to the protocol described by Garbeva et al. ${ }^{49}$. The $16 \mathrm{~S}$ rDNA V3 sequences were amplified by PCR using extracted genomic DNA as a template; the PCR mixture $(25.0 \mu \mathrm{L})$ contained $1 \mu \mathrm{L}$ of DNA template $\left(5 \mathrm{ng} \cdot \mu \mathrm{L}^{-1}\right), 12.5 \mu \mathrm{L}$ of Premix Taq (TaKaRa, Premix Taq Version 2.0), $0.5 \mu \mathrm{L}$ of primers $\left(12.5 \mu \mathrm{g} \cdot \mu \mathrm{L}^{-1}\right)$, and $1 \mu \mathrm{L}$ of bovine serum albumin $\left(20 \mu \mathrm{g} \cdot \mu \mathrm{L}^{-1}\right)$. PCR was performed in a DNA Engine Thermal Cycler (TaKaRa, D-8308), and the PCR primers and programs were provided in the Supplementary Table S1-S2 online.

DGGE analysis was performed using a Dcode Multiple System (Bio-Rad Laboratories Inc., Hercules, CA, USA) using the following protocol: Aliquots $(25 \mu \mathrm{L})$ of the PCR products were loaded onto an $8 \%$ $(\mathrm{w} / \mathrm{v})$ polyacrylamide gel with a denaturant gradient ranging from $40 \%$ to $65 \%$ (16SrRNA gene) and from $45 \%$ to $75 \%$ (PHE gene). Electrophoresis was performed for $12 \mathrm{~h}$ at $120 \mathrm{~V}$ and $60^{\circ} \mathrm{C}$ in $0.5 \times \mathrm{TAE}$ buffer $(20 \mathrm{mM}$ Tris, $10 \mathrm{mM}$ acetic acid, and $1 \mathrm{mM}$ EDTA). Next, gels were soaked in SYBR Green I nucleic acid stain (1:10,000 dilution) for $30 \mathrm{~min}$ and immediately photographed under UV light. Specific bands were excised from the DGGE gel and washed twice with sterilized distilled water. Each band was used as a direct template for PCR to recover DNA fragments separated in a previous round of DGGE. The PCR conditions were identical to those used for the original PCR. The fragments recovered from the PCR were subjected to DGGE again to confirm the equality of their mobility. If a single band appeared in a DGGE gel for one sample, the PCR products were purified using the PCR Cleanup Kit (Axygen, USA) and used for direct sequencing (Invitrogen). When multiple bands appeared in one sample, the bands were repeatedly electrophoresed and excised until only a single band was detectable on the DGGE gel.

FQ-PCR analysis. FQ-PCR analysis was performed using total DNA extracted from rhizosphere bacteria or endophytic bacteria at each sampling site. The experimental system for real-time PCR reaction involved a $20 \mu \mathrm{L}$ reaction and was performed in a 96-well PCR plate. The reaction primers and reaction conditions were as used for PCR-DGGE analysis. The SYBR Premix Ex Taq ${ }^{\mathrm{TM}}$ (Perfect Real Time) kit (TAKARA) was applied in this reaction system. The specific reaction system was as follows: $1 \mu \mathrm{L}$ of DNA template; $1 \mu \mathrm{L}$ of each primer $\left(12.5 \mu \mathrm{g} \cdot \mu \mathrm{L}^{-1}\right)$; SYBR Premix Ex Taq $12.5 \mu \mathrm{L}$; Nuclease-free water $9.5 \mu \mathrm{L}$. Next, the program was started, run status was monitored, baseline cycles were adjusted and threshold values were calculated, and finally real-time data analysis was performed.

Statistical analysis. All data collected were processed using Microsoft Excel 2007. Each data point represents the mean of at least three replicates, and error bars represent standard deviations (SD). The data were statistically analyzed using analysis of variance (ANOVA) with the statistical software package SPSS 13.0. Differences were considered significant at $p$ values $<0.05$, and standard deviations obtained from three parallel samples are shown in the figures as error bars.

\section{References}

1. Simonich, S. C. \& Hites, R. A. Importance of vegetation in removing polycyclic aromatic hydrocarbons from the atmosphere. Nature 370, 49-51 (1994).

2. Ahangar, A. G. Sorption of PAHs in the soil environment with emphasis on the role of soil organic matter: A review. World Appl. Sc. J. 11, 759-765 (2010).

3. Mueller, J. G. et al. Phylogenetic and physiological comparisons of PAH-degrading bacteria from geographically diverse soils. Anton. Leeuw. 71, 329-343 (1997).

4. Kästner, M., Breuer-Jammali, M. \& Mahro, B. Impact of inoculation protocols, salinity, and pH on the degradation of polycyclic aromatic hydrocarbons (PAHs) and survival of PAH-degrading bacteria introduced into soil. Appl. Environ. Microbiol. 64, 359-362 (1998).

5. Guo, C., Zhou, H., Wong, Y. \& Tam, N. Isolation of PAH-degrading bacteria from mangrove sediments and their biodegradation potential. Mar. pollut. bull. 51, 1054-1061 (2005). 
6. Liste, H. H. \& Prutz, I. Plant performance, dioxygenase-expressing rhizosphere bacteria, and biodegradation of weathered hydrocarbons in contaminated soil. Chemosphere 62, 1411-1420 (2006).

7. Ma, B., He, Y., Chen, H. H., Xu, J. M. \& Rengel, Z. Dissipation of polycyclic aromatic hydrocarbons (PAHs) in the rhizosphere: Synthesis through meta-analysis. Environ. pollut. 158, 855-861 (2010).

8. Sheng, X., Chen, X. \& He, L. Characteristics of an endophytic pyrene-degrading bacterium of Enterobacter sp. 12J1 from Allium macrostemon Bunge. Inter. Biodeter. Biodegrad. 62, 88-95 (2008).

9. Ho, Y. N., Shih, C. H., Hsiao, S. C. \& Huang, C. C. A novel endophytic bacterium, Achromobacter xylosoxidans, helps plants against pollutant stress and improves phytoremediation. J. Biosci. Bioeng. 108, S94-S94 (2009).

10. Harish, S. et al. Biohardening with plant growth promoting rhizosphere and endophytic bacteria induces systemic resistance against Banana bunchy top virus. Appl. Soil Ecol. 39, 187-200 (2008).

11. Germaine, K. J., Keogh, E., Ryan, D. \& Dowling, D. N. Bacterial endophyte-mediated naphthalene phytoprotection and phytoremediation. FEMS Microbiol. Lett. 296, 226-234 (2009).

12. Peng, R. H. et al. Phytoremediation of phenanthrene by transgenic plants transformed with a naphthalene dioxygenase system from pseudomonas. Environ. Sci. Technol. 48, 12824-12832 (2014).

13. Peng, A. P., Liu, J., Gao, Y. Z. \& Chen, Z. Y. Distribution of endophytic bacteria in Alopecurus aequalis Sobol and Oxalis corniculata L. from soils contaminated by polycyclic aromatic hydrocarbons. PLoS ONE 8, e83054 (2013).

14. Gaskins, M. H., Albrecht, S. L. \& Hubbell, D. H. Rhizosphere bacteria and their use to increase plant productivity: A review. Agric. Ecosyst. Environ. 12, 99-116 (1985).

15. Knee, E. M. et al. Root mucilage from pea and its utilization by rhizosphere bacteria as a sole carbon source. Mol. Plant-Microbe Interact. 14, 775-784 (2001).

16. Singer, A. C., Crowley, D. E. \& Thompson, I. P. Secondary plant metabolites in phytoremediation and biotransformation. Trends Biotechnol. 21, 123-130 (2003)

17. Söderberg, K. H., Olsson, P. A. \& Bååth, E. Structure and activity of the bacterial community in the rhizosphere of different plant species and the effect of arbuscular mycorrhizal colonisation. FEMS Microbiol. Ecol. 40, 223-231 (2002).

18. Schwaner, N. \& Kroer, N. Effect of plant species on the kinetics of conjugal transfer in the rhizosphere and relation to bacterial metabolic activity. Microb. ecol. 42, 458-465 (2001).

19. Kozdrój, J. \& van Elsas, J. D. Response of the bacterial community to root exudates in soil polluted with heavy metals assessed by molecular and cultural approaches. Soil Biol. Biochem. 32, 1405-1417 (2000).

20. Burd, G. I., Dixon, D. G. \& Glick, B. R. Plant growth-promoting bacteria that decrease heavy metal toxicity in plants. Canad. J. Microbiol. 46, 237-245 (2000).

21. Wang, Y. P. et al. Assessment of microbial activity and bacterial community composition in the rhizosphere of a copper accumulator and a non-accumulator. Soil Biol. Biochem. 40, 1167-1177 (2008).

22. Pritchina, O., Ely, C. \& Smets, B. F. Effects of PAH-contaminated soil on rhizosphere microbial communities. Water Air Soil Pollut. 222, 17-25 (2011).

23. Corgié, S., Beguiristain, T. \& Leyval, C. Spatial distribution of bacterial communities and phenanthrene degradation in the rhizosphere of Lolium perenne L. Appl. Environ. Microbiol. 70, 3552-3557 (2004).

24. Siciliano, S. D. et al. Selection of specific endophytic bacterial genotypes by plants in response to soil contamination. Appl. Environ. Microbiol. 67, 2469-2475 (2001).

25. Chan, S. M. N., Luan, T., Wong, M. H. \& Tam, N. F. Y. Removal and biodegradation of polycyclic aromatic hydrocarbons by Selenastrum capricornutum. Environ. Toxicol. Chem. 25, 1772-1779 (2006).

26. Baldwin, B. R., Nakatsu, C. H. \& Nies, L. Detection and enumeration of aromatic oxygenase genes by multiplex and real-time PCR. Appl. Environ. Microbiol. 69, 3350-3358 (2003).

27. Park, J. W. \& Crowley, D. E. Dynamic changes in nahAc gene copy numbers during degradation of naphthalene in PAHcontaminated soils. Appl. Microbiol. Biotechnol. 72, 1322-1329 (2006).

28. Chin, K. J., Sharma, M. L., Russell, L. A., O'Neill, K. R. \& Lovley, D. R. Quantifying expression of a dissimilatory (bi) sulfite reductase gene in petroleum-contaminated marine harbor sediments. Microb. Ecol. 55, 489-499 (2008).

29. Wang, Y., Xiao, M., Geng, X., Liu, J. \& Chen, J. Horizontal transfer of genetic determinants for degradation of phenol between the bacteria living in plant and its rhizosphere. Appl. Microbiol. Biotechnol. 77, $733-739$ (2007).

30. Lyons, S. R., Griffen, A. L. \& Leys, E. J. Quantitative real-time PCR forPorphyromonas gingivalis and total bacteria. J. Clin. Microbiol. 38, 2362-2365 (2000).

31. Hoque, M. O. et al. Quantitative methylation-specific polymerase chain reaction gene patterns in urine sediment distinguish prostate cancer patients from control subjects. J. Clin. Oncol. 23, 6569-6575 (2005).

32. Briggs, G. G., Bromilow, R. H., Evans, A. A. \& Williams, M. Relationships between lipophilicity and the distribution of nonionised chemicals in barley shoots following uptake by the roots. Pestic. Sci. 14, $492-500$ (1983).

33. Zhu, L. Z. \& Gao, Y. Z. Prediction of phenanthrene uptake by plants with a partition-limited model. Environ. Pollut. 131, 505-508 (2004).

34. McCully, M. E. Niches for bacterial endophytes in crop plants: a plant biologist's view. Funct. Plant Biol. 28, 983-990 (2001).

35. Kluepfel, D. A. The behavior and tracking of bacteria in the rhizosphere. Annu. Rev. Phytopathol. 31, 441-472 (1993).

36. Lodewyckx, C. et al. Endophytic bacteria and their potential applications. Crit. Rev. Plant Sci. 21, 583-606 (2002).

37. Compant, S., Clément, C. \& Sessitsch, A. Plant growth-promoting bacteria in the rhizo-and endosphere of plants: their role, colonization, mechanisms involved and prospects for utilization. Soil Biol. Biochem. 42, 669-678 (2010).

38. Seghers, D., Wittebolle, L., Top, E. M., Verstraete, W. \& Siciliano, S. D. Impact of agricultural practices on the Zea mays L. endophytic community. Appl. Environ. Microbiol. 70, 1475-1482 (2004).

39. Tang, X. J. et al. Influence of heavy metals and PCBs pollution on the enzyme activity and microbial community of paddy soils around an E-waste recycling workshop. Int. J. Environ. Res. Public. Health 11, 3118-3131 (2014).

40. Hassanshahian, M. The effects of crude oil on marine microbial communities in sediments from the Persian Gulf and the Caspian Sea: A microcosm experiment. Inter. J. Adv. Biolog. Biomed. Res. 2, 1-17 (2014).

41. Altimira, F. et al. Characterization of copper-resistant bacteria and bacterial communities from copper-polluted agricultural soils of central Chile. BMC Microbiol. 12, 193 (2012).

42. Hendrickx, B. et al. PCR-DGGE method to assess the diversity of BTEX mono-oxygenase genes at contaminated sites. FEMS Microbiol. Ecol. 55, 262-273 (2006).

43. Perpetuo, E. A. et al. Characterization of the phenol monooxygenase gene from Chromobacterium violaceum: Potential use for phenol biodegradation. Biotechnol. and Bioproc. Eng. 14, 694-701 (2009).

44. Langworthy, D. E., Stapleton, R. D., Sayler, G. S. \& Findlay, R. H. Genotypic and phenotypic responses of a riverine microbial community to polycyclic aromatic hydrocarbon contamination. Appl. Environ. Microbiol. 64, 3422-3428 (1998).

45. Su, Y. H. \& Yang, X. Y. Interactions between selected PAHs and the microbial community in rhizosphere of a paddy soil. Sci. Total Environ. 407, 1027-1034 (2009).

46. Barac, T. et al. Engineered endophytic bacteria improve phytoremediation of water-soluble, volatile, organic pollutants. Nat. Biotechnol. 22, 583-588 (2004). 
47. Barillot, C. D., Sarde, C. O., Bert, V., Tarnaud, E. \& Cochet, N. A standardized method for the sampling of rhizosphere and rhizoplan soil bacteria associated to a herbaceous root system. Ann. Microbiol. 63, 471-476 (2013).

48. Kuklinsky-Sobral, J., Araujo, W. L., Mendes, R., Pizzirani-Kleiner, A. A. \& Azevedo, J. L. Isolation and characterization of endophytic bacteria from soybean (Glycine max) grown in soil treated with glyphosate herbicide. Plant Soil 273, 91-99 (2005).

49. Garbeva, P., Van Overbeek, L., Van Vuurde, J. \& Van Elsas, J. Analysis of endophytic bacterial communities of potato by plating and denaturing gradient gel electrophoresis (DGGE) of 16S rDNA based PCR fragments. Microb. Ecol. 41, 369-383 (2001).

\section{Acknowledgments}

This work was financially supported by the National Science Foundation of China $(41201501,41171380$, 51278252, 21477056), and the Science Foundation of Jiangsu Province, China (BK20130030, BK2012370).

\section{Author Contributions}

J.L., W.T.L. and Y.Z.G. designed the study. A.P.P., J.L. and Z.Y.C. conducted the experiments. A.P.P., J.L. and Y.Z.G. analyzed the data. A.P.P., J.L. and Y.Z.G. wrote the manuscript.

\section{Additional Information}

Supplementary information accompanies this paper at http://www.nature.com/srep

Competing financial interests: The authors declare no competing financial interests.

How to cite this article: Peng, A. et al. Diversity and distribution of $16 \mathrm{~S}$ rRNA and phenol monooxygenase genes in the rhizosphere and endophytic bacteria isolated from PAH-contaminated sites. Sci. Rep. 5, 12173; doi: 10.1038/srep12173 (2015).

(c) (i) This work is licensed under a Creative Commons Attribution 4.0 International License. The images or other third party material in this article are included in the article's Creative Commons license, unless indicated otherwise in the credit line; if the material is not included under the Creative Commons license, users will need to obtain permission from the license holder to reproduce the material. To view a copy of this license, visit http://creativecommons.org/licenses/by/4.0/ 